Chapter 9

\title{
Tectonic Basin Formation in and Around Lake Biwa, Central Japan
}

\author{
Keiji Takemura, Tsuyoshi Haraguchi, \\ Shigekazu Kusumoto and Yasuto Itoh \\ Additional information is available at the end of the chapter \\ http://dx.doi.org/10.5772/56667
}

\section{Introduction}

Located on the convergent margin of the Eurasian plate, the Japanese archipelago features many tectonic, volcanic, and coastal lakes that are well suited for studies of Quaternary intraplate tectonics. A famous and often studied tectonic lake in Japan is Lake Biwa (Figure 1). Along the west coast, an extremely active fault system in Japan designated as the Biwakoseigan Fault zone runs north to south (Figure 1).

The ca. 1.5-Ma-old present Lake Biwa ( $82 \mathrm{~m}$ a s 1.) on south-central Honshu Island is the largest freshwater lake in Japan, measuring $22.6 \mathrm{~km}$ wide by $68 \mathrm{~km}$ long (Figure 1). Lake Biwa is divided into two basins. The Northern Lake is a deep basin with a maximal depth of $104 \mathrm{~m}$ and average depth of $40 \mathrm{~m}$. The much smaller Southern Lake is extremely shallow with average depth of about $3 \mathrm{~m}$. Herein we summarize and discuss that the tectonic basin formation in the paleo and present Lake Biwa basin as an example of intraplate basin formation.

\section{Sedimentary sequences in present Lake Biwa Basin}

Lake sediments are important archives for understanding tectonic history at different scales. Several attempts to recover core sediments from Lake Biwa have been made, mainly in the 65-70 $\mathrm{m}$ deep depression situated in the southern part of the Northern Lake (Figure 1). Horie et al. first recovered a 6-m-long sediment core in 1965 and then an 11.5-m-long piston core in 1967 [2]. In 1971, with considerable effort, they drilled sediments in the same depression (Figure 2) and obtained core samples of about $200 \mathrm{~m}$ in all [3]. Finally, in 1982 and 1983, they recovered a 1400-m-long core covering the entire sediment sequence to the basement. 


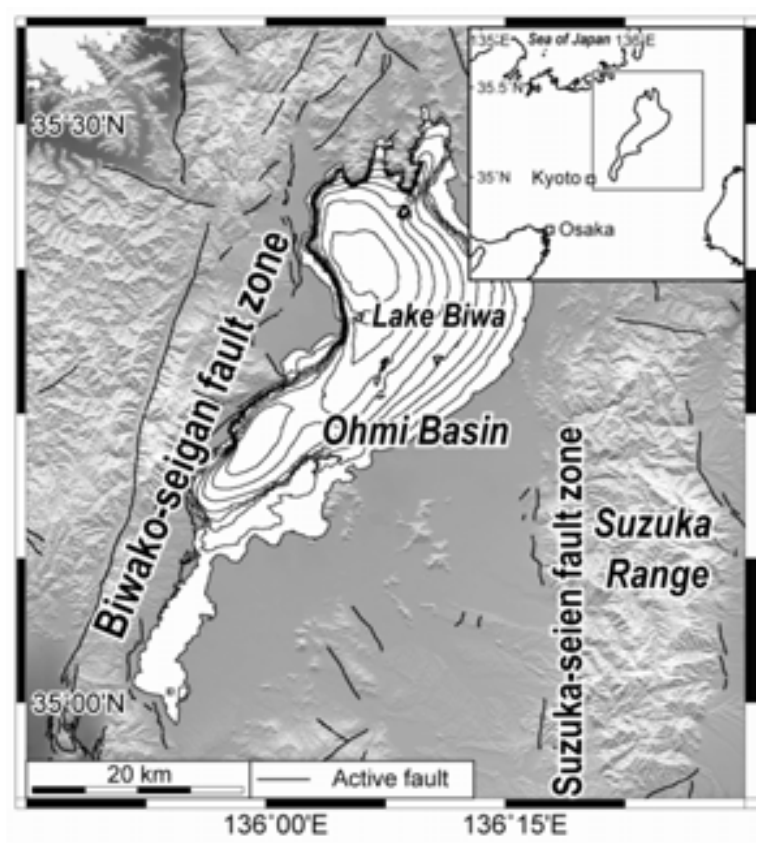

Figure 1. Geomorphology and active faults around Lake Biwa (illustrated by D. Ishimura) Surface traces of active faults are from [1]. This map is from 10m DEM of the Geospatial Information Authority of Japan. The bathymetric contour interval in Lake Biwa is $10 \mathrm{~m}$.

This record confirmed that the basin is filled with lacustrine and fluvial sediments about 800 $\mathrm{m}$ thick with a ca $100 \mathrm{~m}$ thick pebbles and cobbles layer resembling debris flow deposits piled on Mesozoic- Paleozoic basement rocks [5,6]. Sediments were divided into five units based on differences in predominant grain-size distributions $[9,10]$. These units have been named the P (ca 100-m-thick pebble and cobble layer) and fluvial and lacustrine sediments $(\mathrm{Q}, \mathrm{R}, \mathrm{S}$, and $\mathrm{T}$ beds) from deepest to most shallow. The $\mathrm{Q}$ bed is a $72.3 \mathrm{~m}$ thick unit $731.8-804.1 \mathrm{~m}$ below lake floor, mblf) composed of alternating layers of sand, gravel, and silt. The R bed is $149.9 \mathrm{~m}$ thick (581.9-731.8 mblf) and is considered to be continuous with the S Bed above it. Subunits of bluish gray nonlaminated clay and of layers of silt, sand, and sandy gravel alternate at approximately $10 \mathrm{~m}$ intervals throughout this unit. The $S$ bed is $332.4 \mathrm{~m}$ thick (249.5-581.9 mblf) and is believed to be continuous with the overlying T Bed. It consists of thin alternations of sands and silts interspersed with sandy gravels. The T bed is $249.5 \mathrm{~m}$ thick (0-249.5 mblf) and is composed of bluish gray, nonlaminated clay. They contain 54 layers of volcanic ash intercalated throughout them [5]. The uppermost unit ( $\mathrm{T}$ bed) was estimated as having been deposited continuously during the last $430 \mathrm{ka}[5,11]$ (Figure 3). A horizon in Figure 3 is correlated with the bottom of T bed. In 1986, additional samples of 141-m-thick sediment were recovered about $5 \mathrm{~km}$ northeast of older drilling sites (Figure 1; [7]). Although the neighboring (ca. $20 \mathrm{~km}$ ) basin of Lake Suigetsu has varved sediments of the past $150 \mathrm{ka}$ [12], Lake Biwa has 


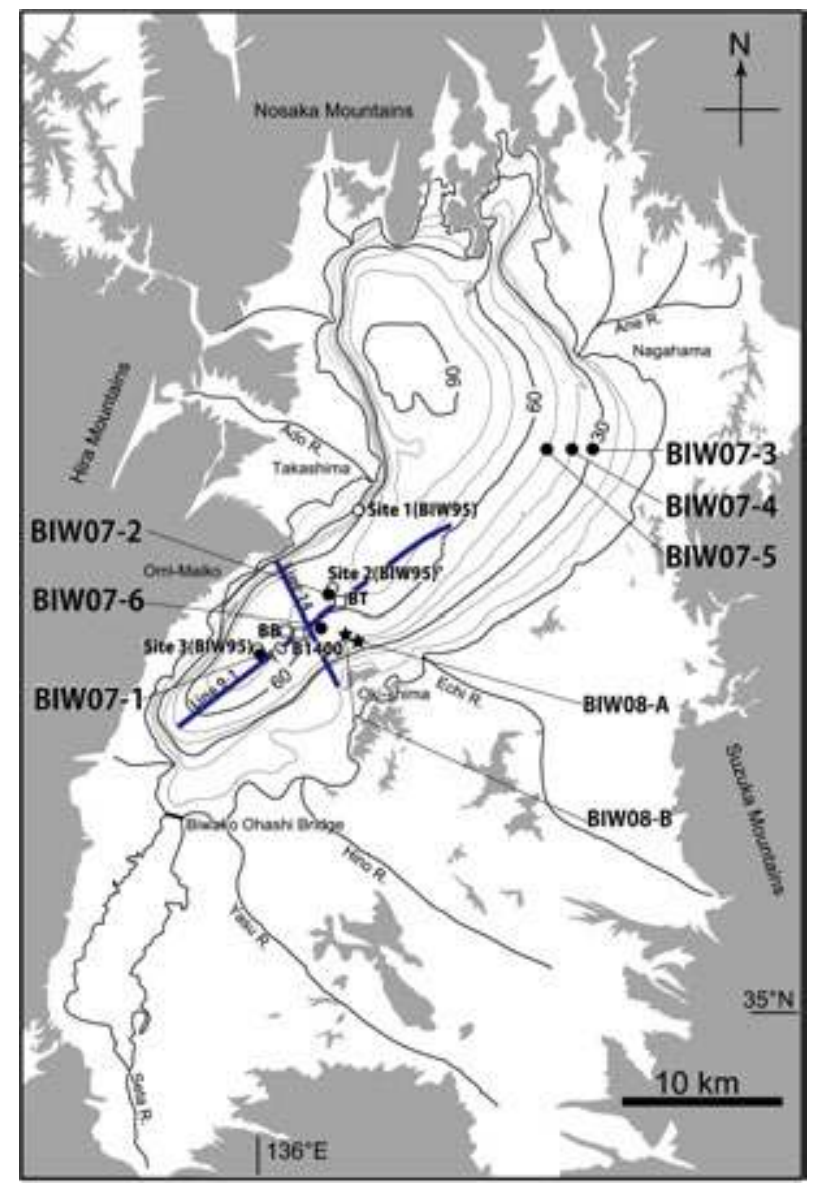

Figure 2. Map showing locations of principal coring sites in Lake Biwa [4]. BB ( $\square: 200 \mathrm{~m}$ drilling in 1971; [3]), B1400 ( $\square: 1400 \mathrm{~m}$ drilling in 1982-1983; [5, 6]), BT ( $\square$ : $141 \mathrm{~m}$ drilling in 1986; [7]), Site 1, 2, 3 (O : BIW95; Piston cores in 1995; [8]), BIW07-1 to BIW07-6 (•:Piston cores in 2007; [4]), BIW08-A and BIW08-B ( $\star$ :Drilled cores in 2008; [4]). Blue line 9-1 and 14 are the survey lines of seismic reflection shown in Figure 3 and Figure 8.

continuous sediments of a million years age. Therefore, the two lake basin records together will facilitate understanding of the Quaternary climate and tectonics at annual to orbital time scales.

Initially, the scientific value of Lake Biwa sediments was not properly acknowledged because the first attempt of fission track dating assigned an incorrect Pliocene age to the basal part. This suggested a markedly crooked sediment accumulation rate curve, casting doubt on the continuity of the Lake Biwa sediment record. In 1993, based on a stratigraphic correlation of the Biwa core with marine data, Meyers et al. [11] reported that the fission track dates were erroneous. Then in 2005, improvements on the fission track timescale identified the paleo- 


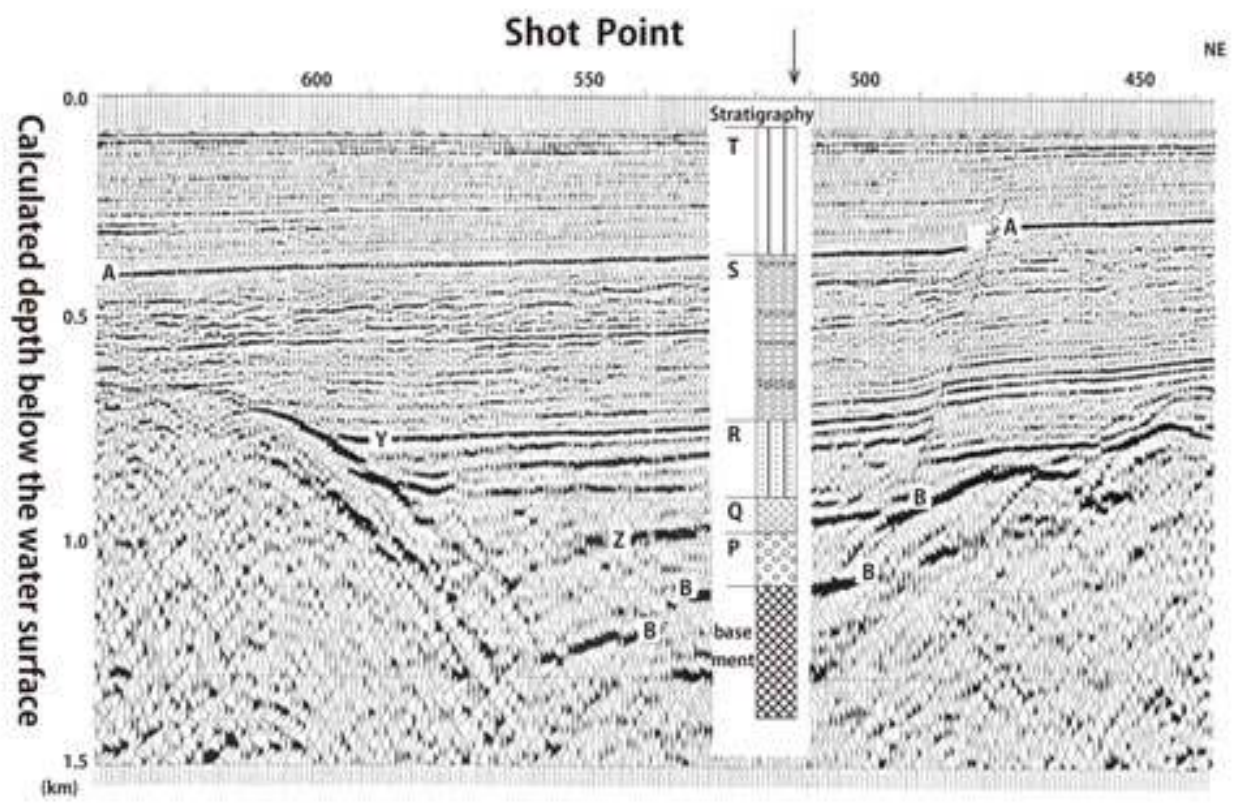

Figure 3. Multichannel seismic reflection profile along the Line 9-1. The core site is indicated by an arrow. The inset roughly correlates reflectors with the stratigraphic column [5].

magnetic reversal near the base as Jaramillo rather than Olduvai, estimating the time coverage of the Lake Biwa core as ca. 1.5 Ma ([13]; Figure 4). Figure 4 shows the nearly linear sediment accumulation from $0.57 \mathrm{~m} / \mathrm{kyr}$ to $0.60 \mathrm{~m} / \mathrm{kyr}$ during the sedimentary record in present Lake Biwa, despite the lithologic units are different. The average sedimentation rate is calculated from the data of depth of $695.6 \mathrm{~m}$ with about $1211 \mathrm{ka}$.

This was evidence for the stable sedimentary environment of the basin and was evidence for the suitability of Lake Biwa as a tectonic archive. Moreover, progress in Japanese tephrochronology in recent decades has enabled the identification of several marker tephras [14] in and around the basin. Lake Biwa is therefore an ideal terrestrial site for exploration of the paleoclimate and tectonic history of eastern Asia during at least the past 1.5 Ma.

Although Lake Biwa sediments have been analyzed using various methods, high-resolution studies have not yet been conducted. In most studies, a single core was obtained at a single site. It was therefore difficult to evaluate the completeness of core recovery and the disturbance of core samples. For example, during deep drilling of 1982 and 1983, it is known that rotary coring caused a disturbance of the upper sediment samples. For a detailed study of the sedimentary record, in 1995, we recovered seven piston cores (10-15 m long) at three localities (sites 1, 2, 3) in the northern part of Lake Biwa (Figure 1). We designed the coring plan (1) to take at least two cores from each site; (2) to take cores at three locations having different 


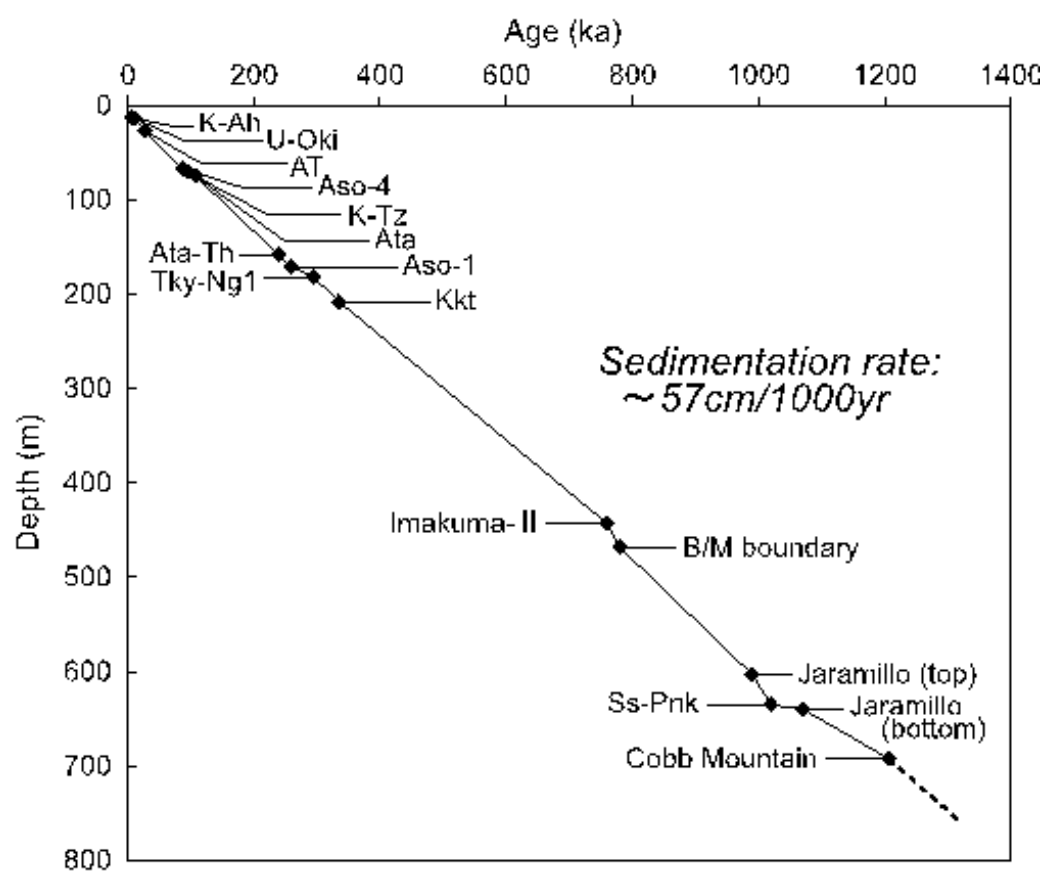

Figure 4. Summary of chronology of core B1400 based on the re-investigation of fission track ages, tephra identification and magnetostratigraphy [13]. Tephra horizons: K-Ah, U-Oki, AT, Aso-4, K-Tz, Ata, Ata-Th, Aso-1, Tky-Ng1, Kkt, Imakuma II, Ss-Pink; Paleomagnetic information: B/M (Brunhes/Matuyama) boundary, top of Jaramillo event, bottom of Jaramillo event, Cobb mountain event.

sedimentation rates, and (3) to recover the longest possible undisturbed sediment sequence. Analyses of the core samples include paleomagnetism, environmental magnetism, physical properties, organic and inorganic chemistry, pollen analysis and ${ }^{14} \mathrm{C}$ dating. We also demonstrated that magnetic susceptibility data are extremely useful to find microscopic tephra horizons, and establish correlation and age assignment of core sediments from different locations.

Drilling challenges are continuing for high-resolution studies of island arc tectonics. In 2007 and 2008, we obtained six new piston cores covering at least $50 \mathrm{ka}$, two longer cores covering $300 \mathrm{ka}$ [4], and 300-km-long shallow seismic surveys. Various interdisciplinary analyses are expected to generate high-resolution records of the dynamics of the tectonic convergence. Sato et al. [15] described that two stages indicating shallow lacustrine delta formation were intercalated with sediment cores during $300 \mathrm{ka}$ at the present depth of 50m. This intercalation is important evidence of tectonic deformation of the lake basin from coastal area migration. 


\section{Active tectonics and geophysical data related to present Lake Basin}

At Lake Biwa, plate motion-related basin formation can be generalized because the Lake Biwa basin formation apparently resulted from subduction of the Philippine Sea plate into the Eurasian plate. Tectonic approaches on the Lake Biwa sediment therefore provide a case study for basin-forming mechanisms related to plate subduction activity, which is applicable to other active subduction zones throughout the world.

Lake Biwa is the largest and oldest fresh-water lake in Japan. Its surrounding geology comprises Mesozoic-Paleozoic formations, Cretaceous Granitic Rocks and Volcanic Rocks, Miocene sedimentary rocks, Plio-Pleistocene ancient lake sediments (Kobiwako Group in Paleo-lake Biwa), terrace deposits, and alluvium.

The present Lake Biwa, surrounded by several active faults, is a tectonic basin with a long history extending from about $1.5 \mathrm{Ma}$ to the present day. Historical earthquake records exist around Lake Biwa region. Lake Biwa is located in the southwestern Japan, which is considered in the area under the east-west compressional stress state from geophysical, topographical and Quaternary geological information [16]. Huzita [16] reported a triangular neotectonic province designated as "Kinki Triangle" (Figure 11 inset) with the E-W compressional stress state and the basin and mountain topography from east to west in the district. In central Japan, including the mountainous region in Chubu district (east of Kinki district) and Chugoku district (west of Kinki district), we can recognize the clear conjugate fault system, and active faults with NWSE direction of left lateral transcurrent component, and those with NE-SW direction of right lateral component, and also in Kinki district, reverse fault system with N-S direction are recognized accompanied with transcurrent fault system (Figure 5). This evidence implies that this area is influenced by the E-W compressional stress state. The force from the Pacific Plate movements and oblique subduction movements of the Philippine Sea Plate influences the Kinki District. According to the combination of both forces, E-W compressional stress occurs in southwestern Japan. Lake Biwa region is located at northern part of "Kinki Triangle" region. Most active and highest rate of activity active fault in this region is the Biwako-seigan Fault zone, which runs along the west coast of Lake Biwa with reverse faulting. Biwako-seigan Fault zone is about $59 \mathrm{~km}$ long with reverse fault sense of east side subsidence. The activity of southern part of the fault is calculated from about $1.4 \mathrm{~m} / \mathrm{kyr}$ of average movement and recurrent interval is calculated as about $4.5-6.0 \mathrm{kyr}$ with latest event of $1185 \mathrm{AD}$. Relative movement of single event is inferred about 6-8 $\mathrm{m} \mathrm{[17].}$

Deep seismic reflection survey and gravity measurement through the 1970s and early 1980s yielded information related to the basement topography (Figures 6-9), and revealed a tilting structure from east to west (Figure 8). However, the deepest part is located in the Northern Lake basin ("Hokko basin"), where Prof. Horie's team drilled in the early 1980s from the seismic reflection survey. A seismic reflection survey revealed the existence of active fault in the deep basin. The lithostratigraphical information indicated the subsidence history of the present lake basin during about $1.5 \mathrm{my}$. The recent subsidence rate is calculated as $0.74-\mathrm{m} / \mathrm{kyr}$ by data of the T bed (thickness $250 \mathrm{~m}$, duration $430 \mathrm{kyr}$, water depth $68 \mathrm{~m}$ ), because $\mathrm{T}$ bed is the sediment under pelagic environment. Shallow seismic reflection surveys conducted in the 


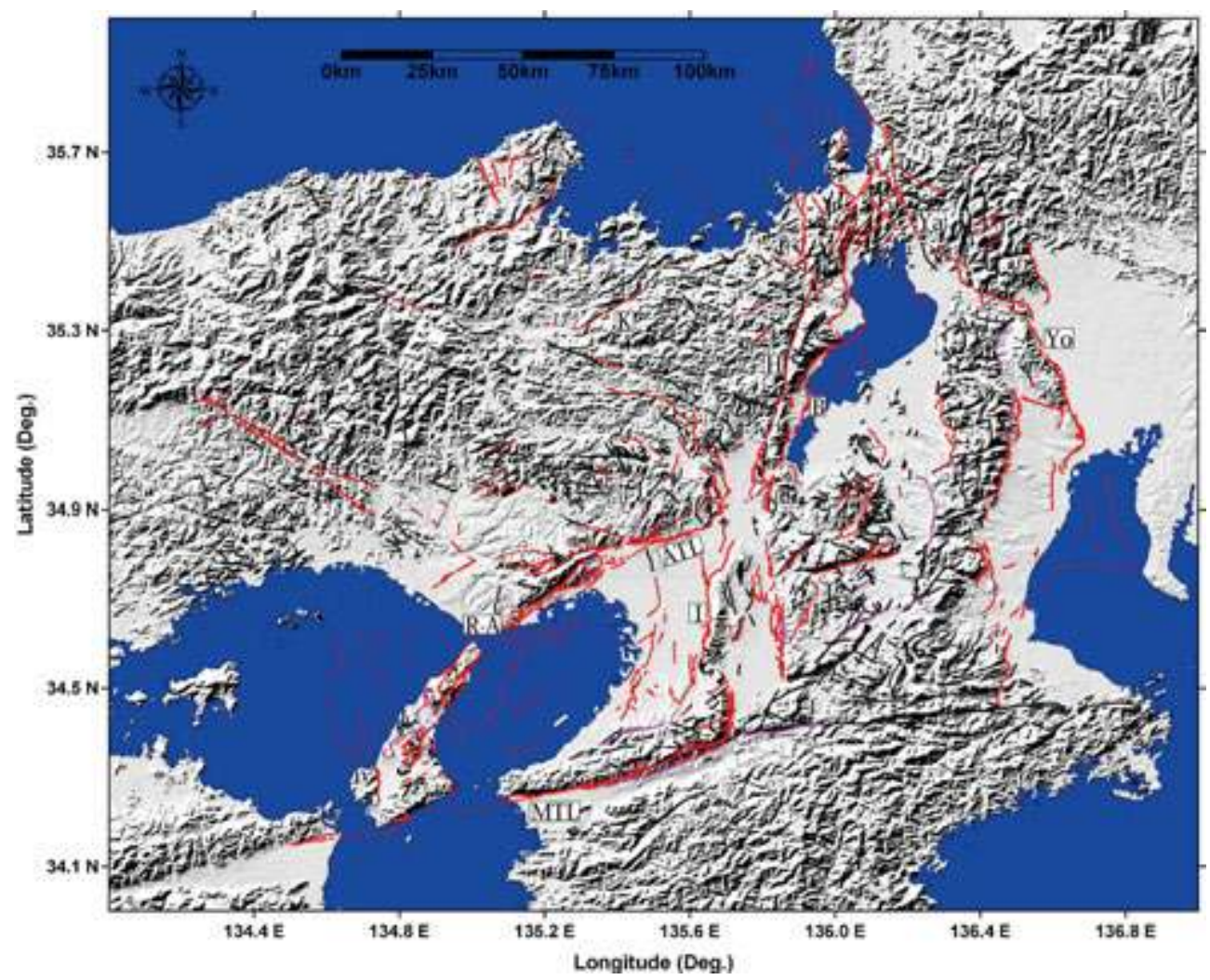

MTL: Median Tectonic Line, ATL: Arima Takatsuki Tectonic Line, R-A: Rokko-Awaji fault zone, I: Ikoma Fault zone, K: Kambayashi Fault, H: Hanaore Fault, B: Biwako-seigan Fault zone, Ya: Yanagase Fault zone, Yo: Yoro Fault zone

Figure 5. Active fault system in Kinki district [18]

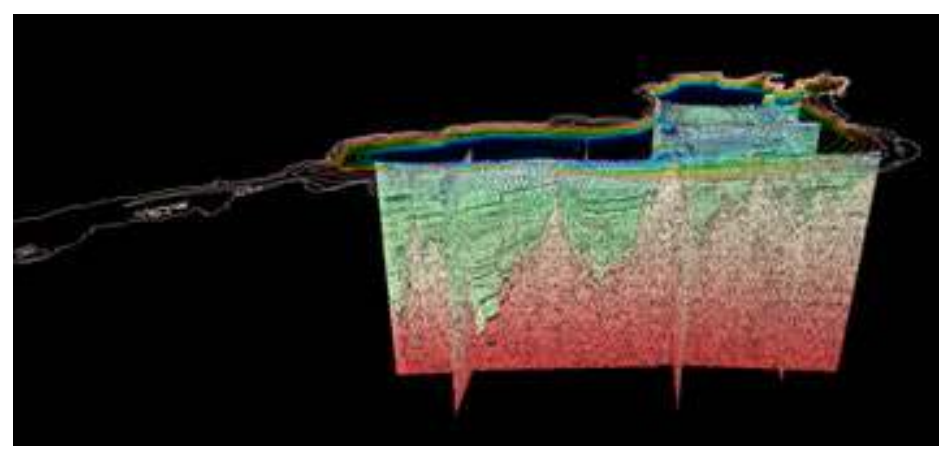

Figure 6. Seismic reflection survey (example of long section of Line 9) (drawn from [19]) 
1980s, 1990s and 2007 show the distribution of active fault traces and size of displacement accompanied with the activity of Biwako-seigan Fault zone along the coast of Lake Biwa.

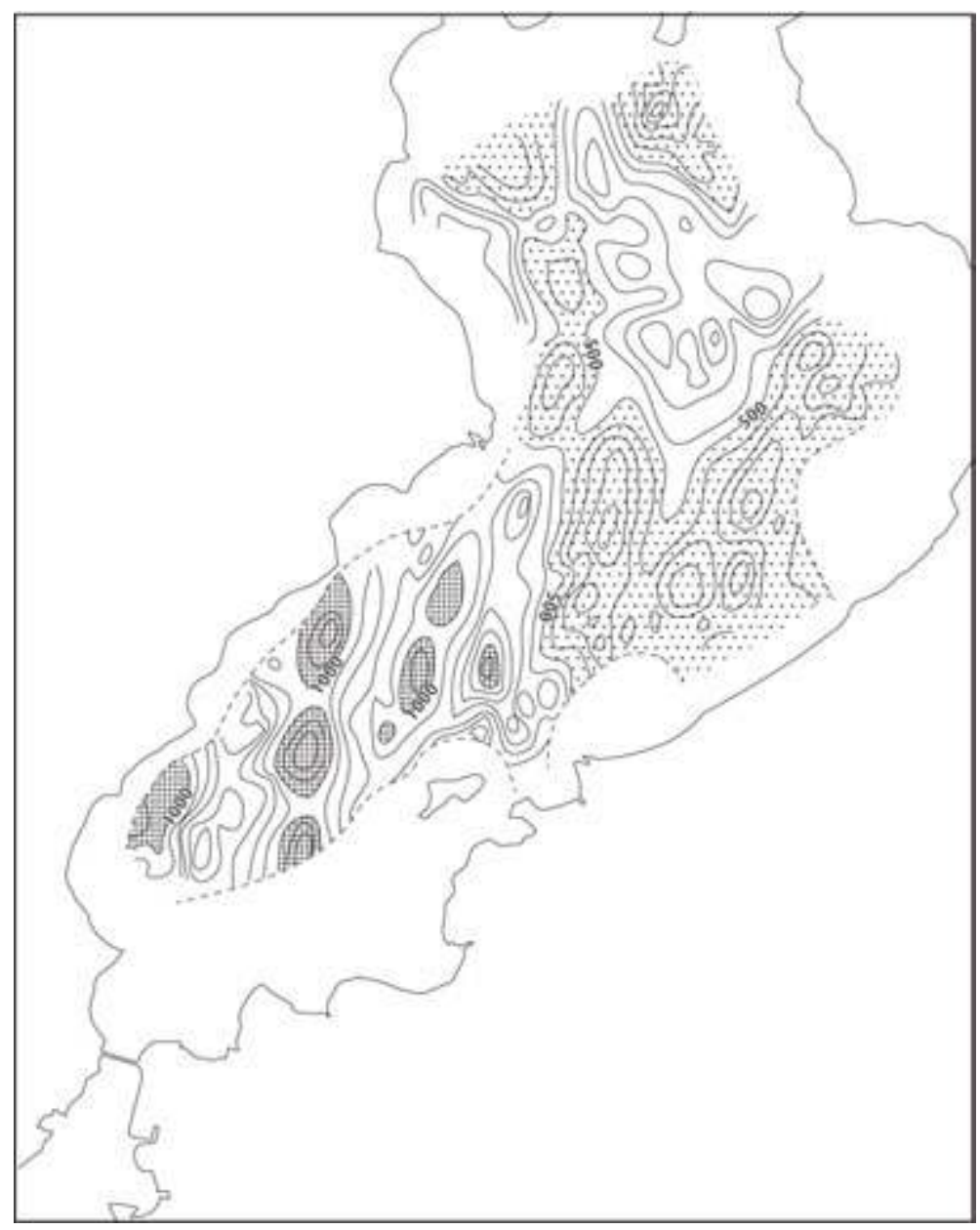

Figure 7. Basement structure revealed by seismic reflection survey [19] Meshed part: depth of basement more than 1 , $000 \mathrm{~m}$. Dotted part: depth of basement lower than 500-m. 


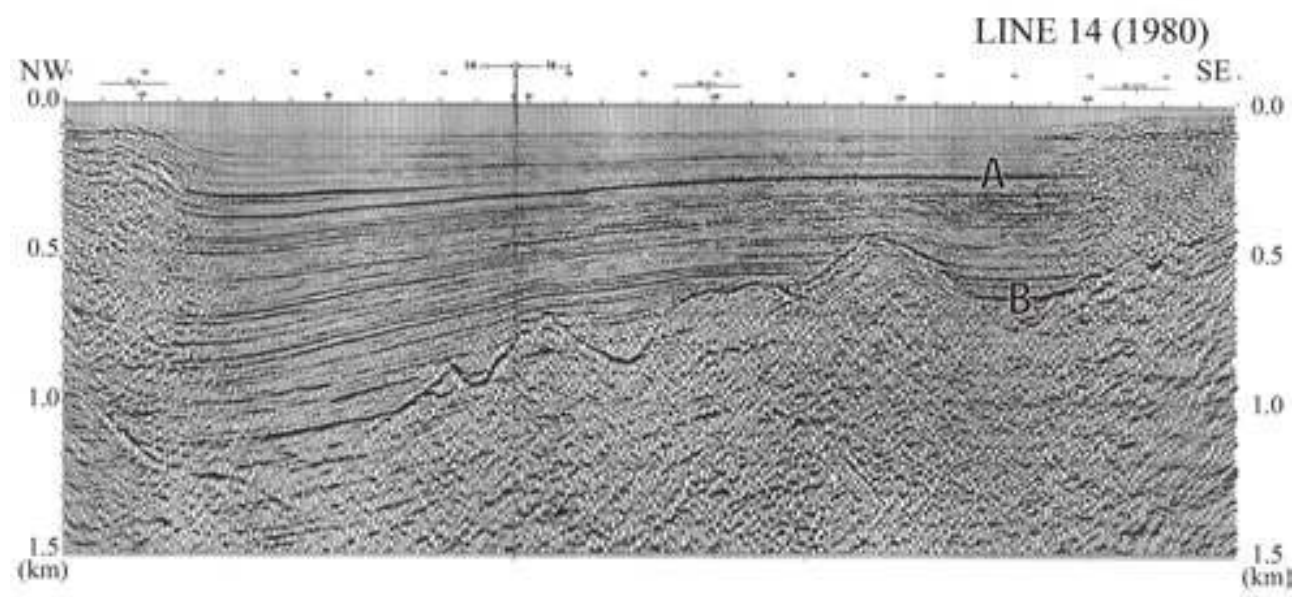

Figure 8. Tilting structure from east to west revealed by sediment structure including horizon A indicating the boundary of T and $\mathrm{S}$ bed [5]. Survey Line is shown in Figure 2.

A gravity survey revealed that the lowest Bouguer anomaly area is in the north lake basin. We show the Bouguer gravity anomaly map around our study area (Figure 10). This Bouguer gravity anomaly map is based on gravity mesh data reported by [20]. The Bouguer density is $2670 \mathrm{~kg} / \mathrm{m}^{3}$.

Gravity anomaly in this area is characterized by the negative gravity anomalies caused by intra-arc sedimentary basins and isostasy attributable to the loading of mountains in central Japan. In this region, the Nohbi Plain, the Ise Plain, the Ohmi Plain including Lake Biwa, the Kyoto Basin, the Nara Basin, the Osaka Plain, the Osaka Bay, and the Sanda Basin are distributed from east to west. Each basin or plain has negative gravity anomalies correspond individually to intra-arc basins. Almost all local negative gravity anomalies in these negative anomalies are included to the active tectonic zone during the Quaternary called "KinkiTriangle" (e.g., [21] Figure 11inset).

Two large negative gravity anomaly areas exist in the "Kinki-Triangle" area. They are the Osaka Bay area and Lake Biwa area (the Ohmi Plain). Negative gravity anomalies around the Osaka Bay and the Lake Biwa respectively reach $-15 \mathrm{mGal}$ and $-60 \mathrm{mGal}$.

Negative gravity anomalies in the Osaka Bay area are known to be explainable by sediments accumulated in and around the Osaka Bay (e.g., [22]; [23]). These negative gravities are divided by some active faults. In contrast, negative gravity anomalies in the Lake Biwa area are known to be unexplainable using the distribution of soft sediments in the lake (e.g., [24]). Nishida et al. [24] reported that depression of the Conrad surface or existence of very low density materials because of faulting is necessary to explain the gravity lows reaching $-60 \mathrm{mGal}$. 


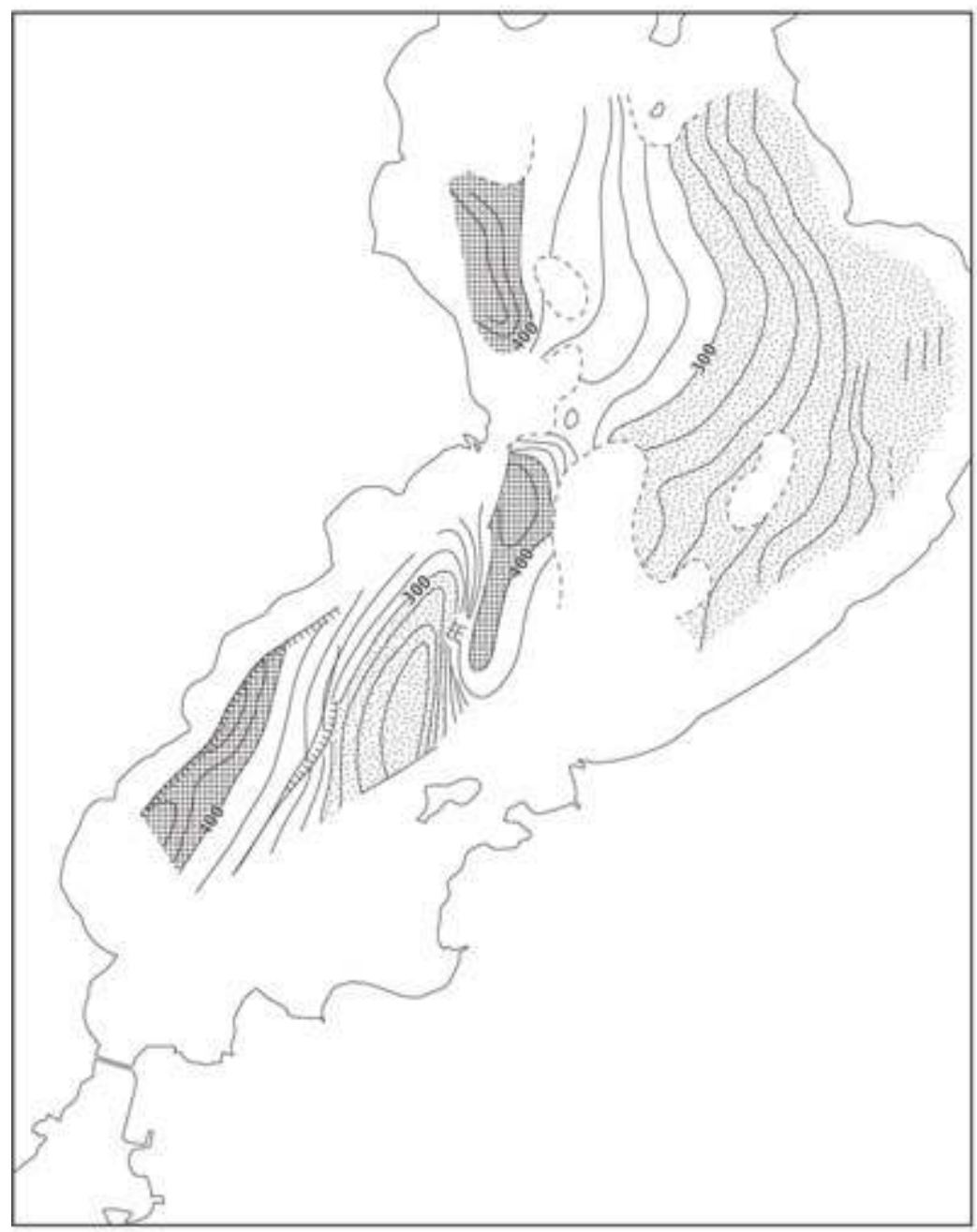

Figure 9. Active structure revealed by horizon A (Boundary of T and S bed) since about $0.43 \mathrm{Ma}$ ) of the seismic reflection survey [19] Meshed part: depth of A horizon more than 400 m, Dotted part: depth of A horizon lower than $300 \mathrm{~m}$

\section{Basin formation and migration in central Kinki since the Pliocene}

Three sedimentary basins are arranged E-W latitudinally in the eastern part of "Second Setouchi Inland Depression of [25]: Lake Tokai, Paleo-Lake Biwa and Paleo-lake (bay) Osaka. All are filled with the Plio-Pleistocene deposits (Figure 11). They are respectively named Tokai, 


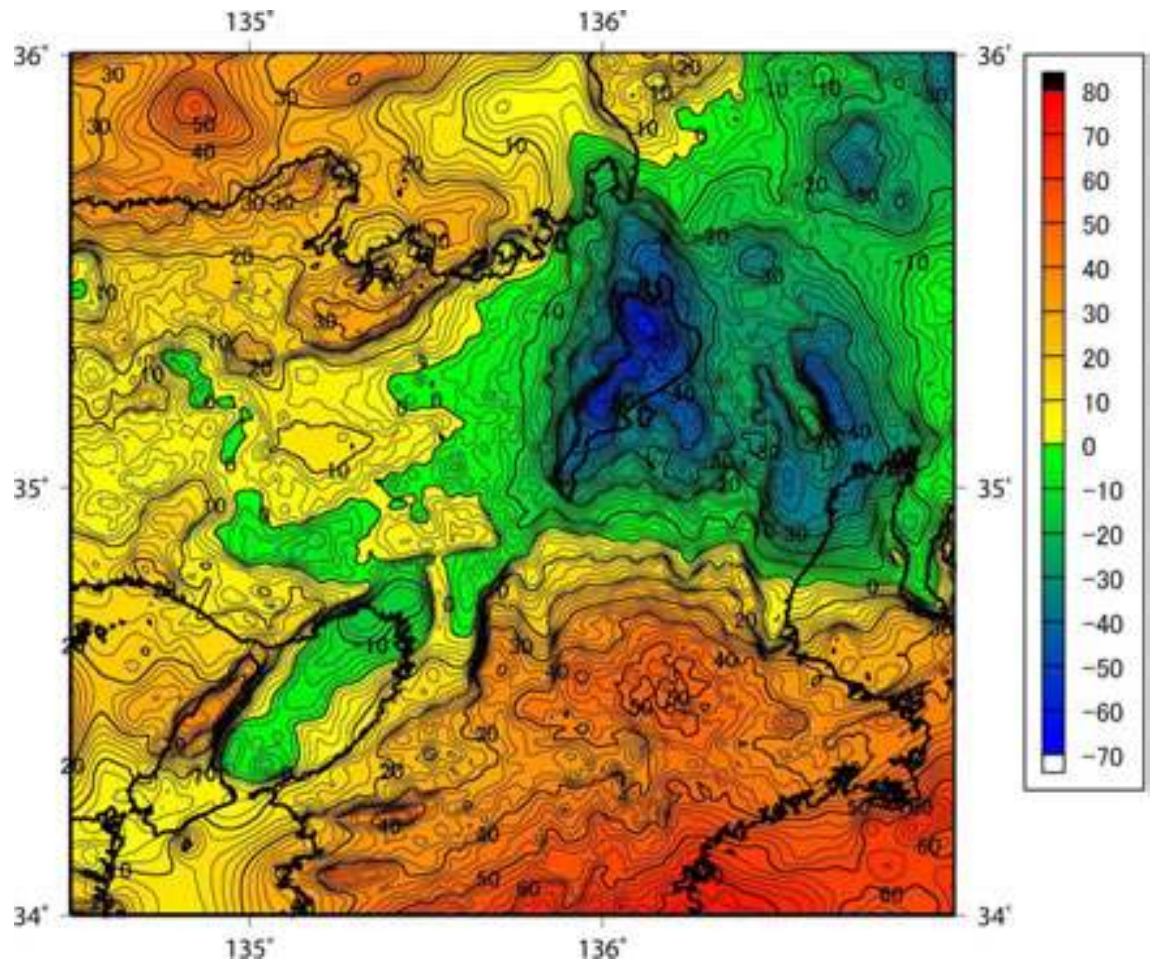

Figure 10. Bouguer gravity anomaly map. The Bouguer density is $2670 \mathrm{~kg} / \mathrm{m}^{3}$, and contour interval is $2 \mathrm{mGal}$

Kobiwako, and Osaka Groups. Comparing of the sedimentary basin transition between PaleoLake Biwa and Lake Tokai, the geohistory in central Kinki Region is known subdivisible by tectonosedimentary facies of about 3.0 Ma and 1.2-1.5 Ma (Figures 12,13) which suggests that the change of tectonic stress state of this province took place simultaneously throughout these sedimentary basins. To complete the geohistory of Paleo-lake Biwa, patterns of sedimentary basin transition must be discussed. According to Yokoyama ([26], [27]), the geohistory of PaleoLake Biwa has four stages: Older I, Older II, Actual I, and Actual II. First, Paleo-Lake Biwa appeared in the Iga Basin and clay-dominant sediments were deposited in the water body ("Iga-ko") ( $\mathrm{a}$ and b in Figure 12) [28]. In the second, the sedimentary basin center shifted its place to the north from Iga Basin to Ohmi Basin, forming a stable water body ("Sayama-ko") with massive clay deposition (c and d in Figure 12). Northward shifting of the sedimentary basin was inherited (Older II Stage) (e and f in Figure 13). During the time from Older II stage to Actual I stage, the center of the sedimentary basin migrated northwestward on a large-scale. Great amounts of gravel are represented as final sediments of Older II stage (g in Figure 13). The sedimentary basin of Actual I stage shifted its place gradually to west, accompanied by upheaval of the eastern mountain area. This explanation is supported by results of lithology, paleocurrent and sedimentological studies of the deposits of the Kosei area and data from 1,000 


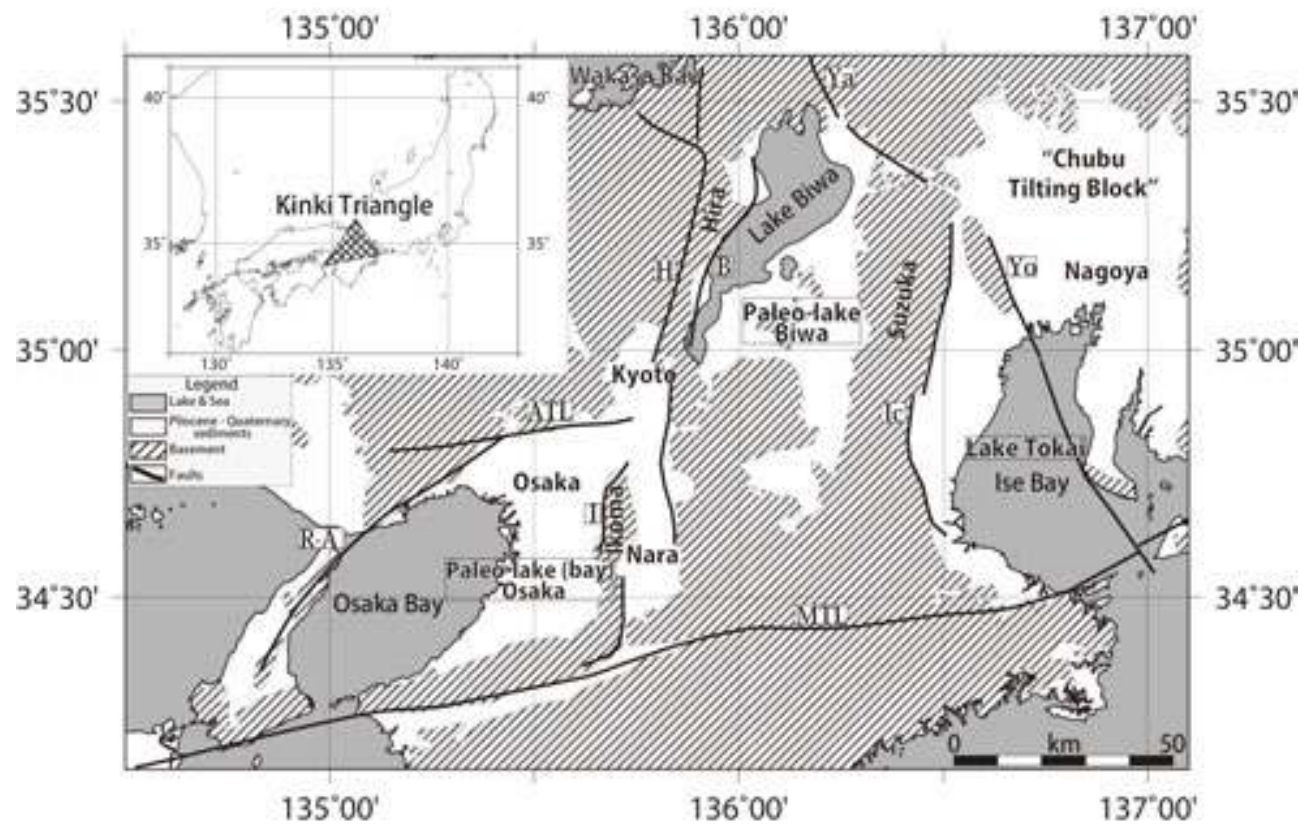

Figure 11. Basement and Pliocene-Quaternary sediment distribution in and around Lake Biwa and Ise Bay region. "Kinki Triangle" region is shown in inset figure. Paleogeographical regions such as "Chubu Tilting Block", Lake Tokai, Paleo-lake Biwa, and Paleo-lake (bay) Osaka are shown. MTL: Median Tectonic Line, ATL: Arima-Takatsuki Tectonic Line, I: Ikoma Fault, H: Hanaore Fault, B: Biwako-seigan Fault zone, Ya: Yanagase Fault, Ic: Ichishi Fault, Yo: Yoro Fault

m drilling cores at the rivermouth of the Yasu River [29]; [30]; [31]. The gravel of the uppermost part of the Kobiwako Group in Kosei Area (western side of present Lake Biwa) constitutes sediments of the last Actual I stage. These gravels were the first sediments from present western Hira Mountains. Subsequently, the crustal movements along the Katata Fault (southern part of Biwako-seigan Fault zone) became more active. Thereafter, in actual II stage, the area of actual northern lake ("Hokko") basin of present Lake Biwa began to subside rapidly.

The process of basin transition in and around Paleo-Lake Biwa is summarized as follows:

1. In the early stage, the sedimentary basin appeared in the southern area of the basin, and migrated gradually to the north in Older Stage I.

2. Subsequently, the sedimentary basin migrated northwestward on a large scale in Older Stage II.

3. The sedimentary basin migrated gradually to the west. Finally, it is divided by the structural movements in N-S trend accompanied rapid subsidence of the eastern area (rapid upheaving of western area) in Actual stage I and Actual stage II of the present Lake Biwa basin formation. 

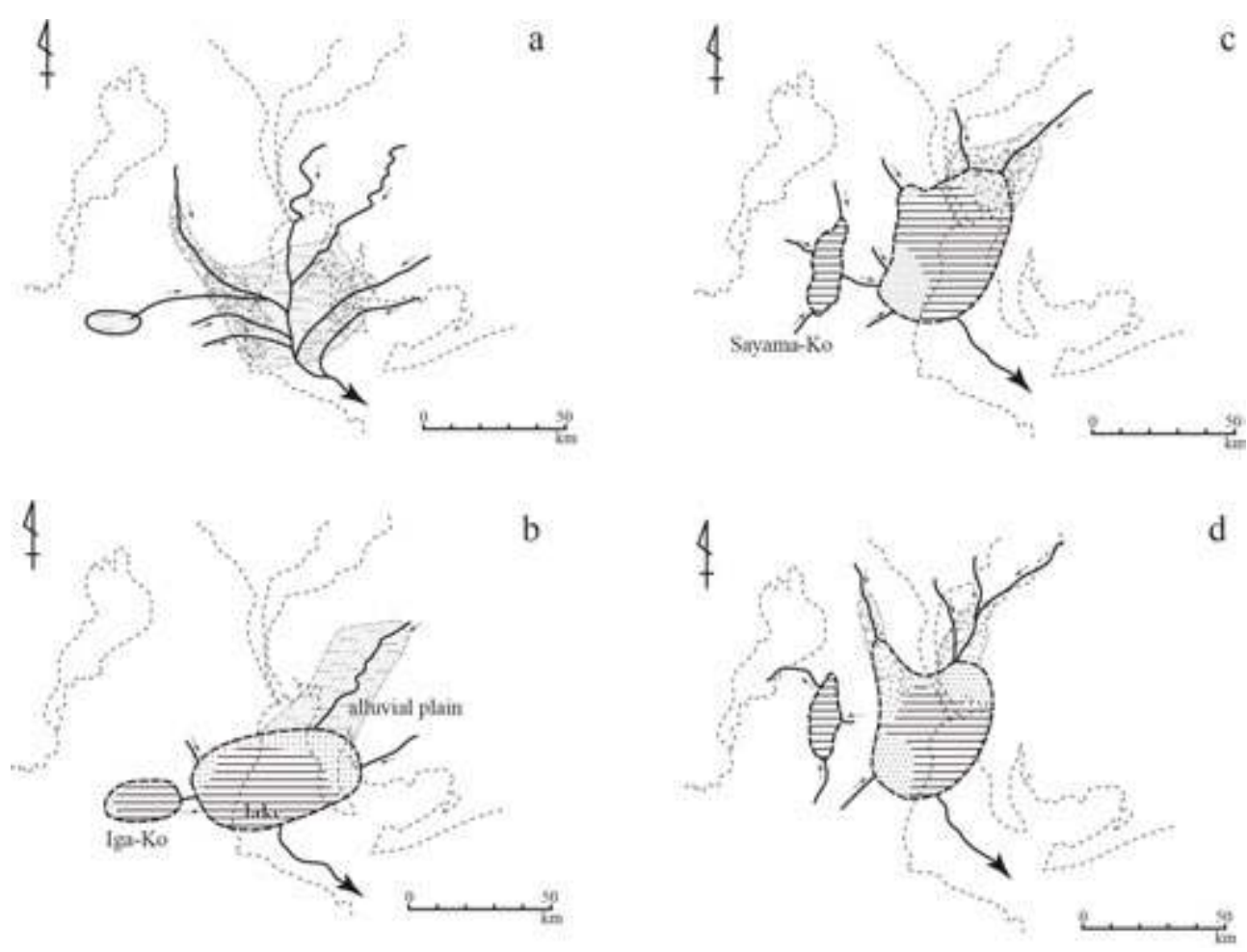

Figure 12. Paleogeographic map of the central Kinki Region including Paleo-Lake Biwa and Lake Tokai area from the early Pliocene to 1.2 - 1.5 Ma [32] a: Initial Stage I of Lake Tokai and Initial Older Stage of Paleo-Lake Biwa, b: Stage I of Lake Tokai and Older Stage of Paleo-Lake Biwa, c: d: Older stage II of Paleo-Lake Biwa and Stage II of Lake Tokai

\section{Tectonic basin formation in and around Lake Biwa: Chronological development and mechanism}

As described previously, the geohistory in central Kinki region had two conspicuous episodes of ca 3.0 Ma and of ca 1.2-1.5 Ma. A similar pattern of basin transition was revealed as recognized in both sedimentary basins of Lake Tokai and Paleo-lake Biwa (Figure 14), which suggests that the changes of the tectonic stress state were common throughout that province. The sedimentary basins before ca 3.0 Ma (Stage 1 of Lake Tokai and older I stage of Paleo-lake Biwa) are characterized mainly by E-W arrangement of depressional zone and their northward migration. Those characteristics might be attributable to the upheaval of the southern area under the tectonic stress state in N-S direction. However, in the middle of Stage 1, Lake Tokai received a large amount of gravel supply from the east, which was related to the movements of "Chubu Tilting Block". Kuwahara[33] discussed tectonism of eastern area of Ise Bay (the area from Nohbi Plain to mountains). He stated that this area had received tilting movement since Pliocene and this movement formed the topographic contrast between the sedimentary 

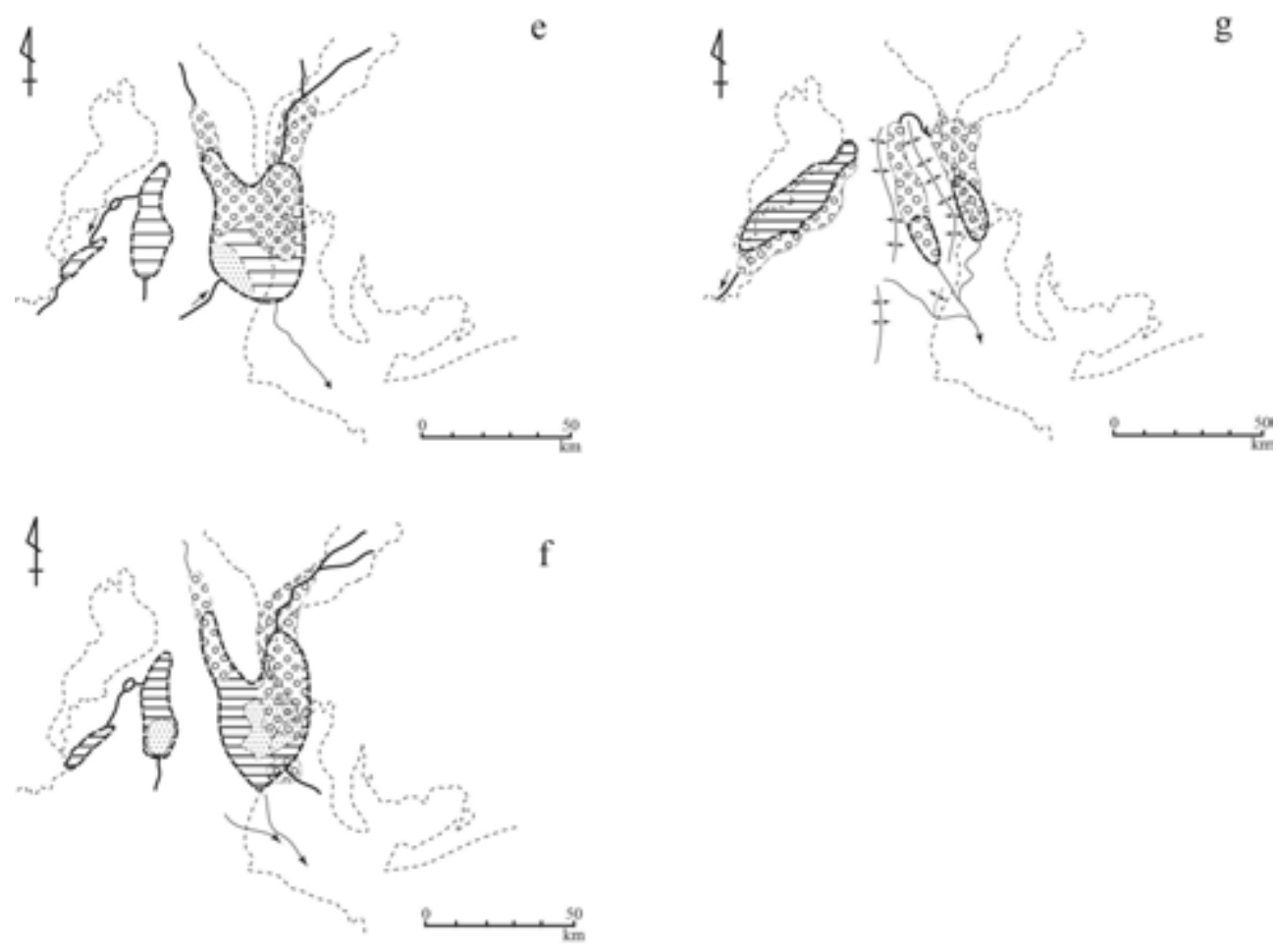

Figure 13. Paleogeographic map of the central Kinki Region including Paleo-Lake Biwa and Lake Tokai area [32] e: \& f: Older stage II of Paleo-Lake Biwa and Stage II of Lake Tokai, g: final stage of Older stage II of Paleo-Lake Biwa and Stage II of Lake Tokai

basin of Lake Tokai and eastern upheaving area. He called this tilting block as "Chubu Tilting Block". A large amount of gravel supply suggests the beginning of new structural control superposing the older one. At ca 3.0 Ma, the Lake Tokai sedimentary basin migrated northwestward.

Subsequently, the sedimentary basin of Lake Tokai migrated to the west as a whole, although slightly northward, because of active movement of "Chubu Tilting Block" under the stress state of the E-W trend. However, during the same time interval, the sedimentary basin of Paleolake Biwa migrated gradually northward by the upheaval of southern area. At the time of ca 1.2 Ma, the sedimentary basin of Lake Tokai became to extinct, accompanying the upheaving of the Suzuka and Yoro mountains with a N-S structural trend. It was peculiar that the sedimentary basin of Paleo-lake Biwa transferred its position northwestward. Thereafter, it migrated westward gradually by tilting of the eastern area. This fact shows the origination of conspicuous movement under E-W tectonic stress in the Ohni Basin.

In this way, the sedimentary basin migration in Lake Tokai and Paleo-lake Biwa is commonly explained by the hypothesis of interaction between upheaving of the southern area and tilting 


\section{PALEO-LAKE BIWA}

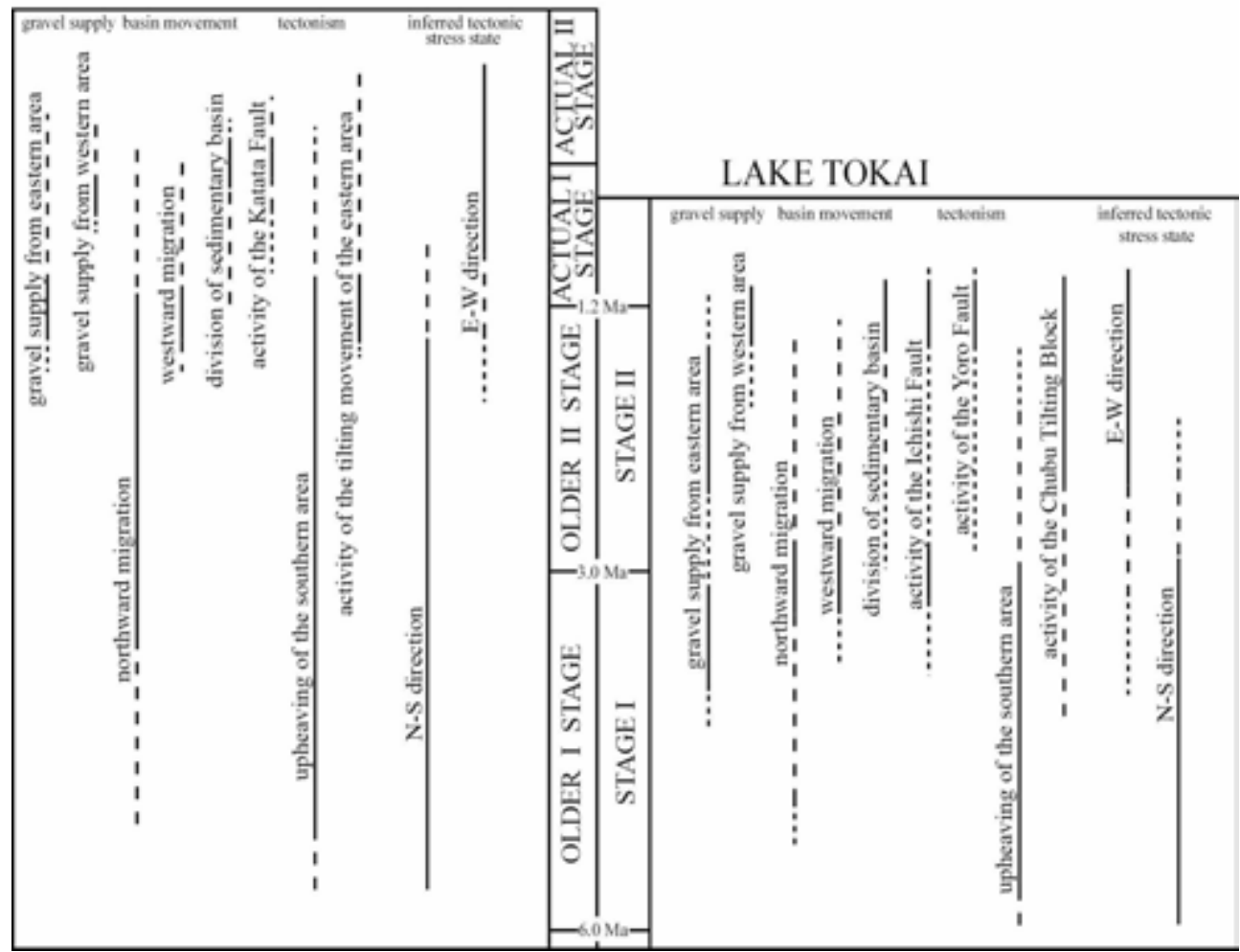

Figure 14. Tectonic implications in central Kinki Region including Paleo-Lake Biwa and Lake Tokai area [32]

of the eastern area (Figure 14). Conclusively we proposed an idea that the deposition in the central part of Kinki region since the Pliocene was under the influence of two superposed tectonic stress states represented by upheaving of the southern area and tilting of the eastern area. Hitherto, Huzita [34] have stated that the tectonic stress state change since Miocene took place in the Inner zone of southwestern Japan during the time of Pliocene and Pleistocene. This change from N-S compressional stress state to E-W one was conspicuous. Therefore, the results of the present work are not contradictory to that idea. In fact, the results confirm the chronological setting and detailed process of tectonosedimentary turnover since the Pliocene.

\section{Present Lake Biwa Basin and tectonosedimentary implications}

Interruptions in the sedimentary record are commonly regarded as evidence of tectonic changes in a lake basin. Major unconformities exist in the core lithology and seismic profiles at the B Horizon separating the P Bed from the basement rocks and at the Z Horizon between 
the Q Bed and the P Bed (Figure 3). The alternating characteristics of the $S, R$, and $Q$ beds indicate short-term cycles in the depositional environment. These cycles may represent periods of uplift of surrounding areas, with subsequent erosional readjustments, or periods of subsidence of the lake basin with subsequent infilling. A study of the lithology and chronology of the Kobiwako Group, the Plio-Pleistocene freshwater sediments distributed around Lake Biwa, reveals that the history of this basin is divisible into two main stages; the Older and the Actual [27]. The deposits of the Older Stage are mainly distributed southward of the present Lake Biwa. Accordingly, the sedimentary depocenter of the Older Stage was located southward of the modern Lake Biwa. Between the Older Stage and the Actual Stage, the depocenter evidently shifted northward to its present location, as indicated by the stratigraphy and chronology of the Kobiwako Group, creating the basin of modern Lake Biwa. Large amounts of gravel began to deposit at the northern part of the Older Stage Lake Biwa basin starting about 1.5 Ma. This occurrence is thought to record the beginning of the migration of the lake depocenter. The R bed corresponds to the sediments of the early stage of Actual Stage. The upper part of the $S$ bed and the entire T bed represent the Actual Stage. The high and constant sedimentation rates within the drilling sequences in present Lake Biwa represent a time of rapid infilling. Rapid subsidence was necessary for the deposition of the continuous sequence in the present Lake Biwa with a sedimentation rate of $0.57 \mathrm{~m} / \mathrm{kyr}$ [13] and inferred a subsidence rata of $0.74 \mathrm{~m} / \mathrm{kyr}$ from the data of age of $\mathrm{T}$ bed and water depth at the $1400 \mathrm{~m}$ drilling site. Reconstruction of these tectonic implications cannot be done competently from data from one core site, and we must use surrounding geological data and geophysical data.

Figure 15 shows the first-order horizontal derivative of the Bouguer gravity anomalies (the horizontal gradient of gravity anomaly) more than $2 \mathrm{mGal} / \mathrm{km}$ and contour interval is $1 \mathrm{mGal} /$ $\mathrm{km}$. The horizontal gradient of gravity anomaly $\left(\Delta g_{h g}\right)$ is defined as the following equation.

$$
\Delta g_{h g}=\sqrt{\left(\frac{\partial g(x, y)}{\partial x}\right)^{2}+\left(\frac{\partial g(x, y)}{\partial y}\right)^{2}}
$$

Here, $g(x, y)$ are gravity anomaly data given on $x y$ mesh with a constant interval.

The horizontal gradient of gravity anomaly emphasizes shorter wavelength signals of subsurface structures. Therefore, it is a good indicator of a conspicuous density change and/or a large fault. High gradient anomalies of greater than $2 \mathrm{mGal} / \mathrm{km}$ correspond well with large faults and tectonic lines such as the Rokko-Awaji fault zone, Arima-Takatsuki tectonic line, Ikoma fault, Kanbayashigawa fault, Hanaore fault, Biwako-seigan fault and others. They have NE-SW and E-W trends in their strike directions. However, distribution of high gradient anomalies around the Lake Biwa is extremely complex. It is difficult to find a specific trend in the strike directions of the horizontal gradient of gravity anomaly. As one reason, it can be inferred that they reflect subsurface structures caused by extreme crustal activities including faulting during the Quaternary. 


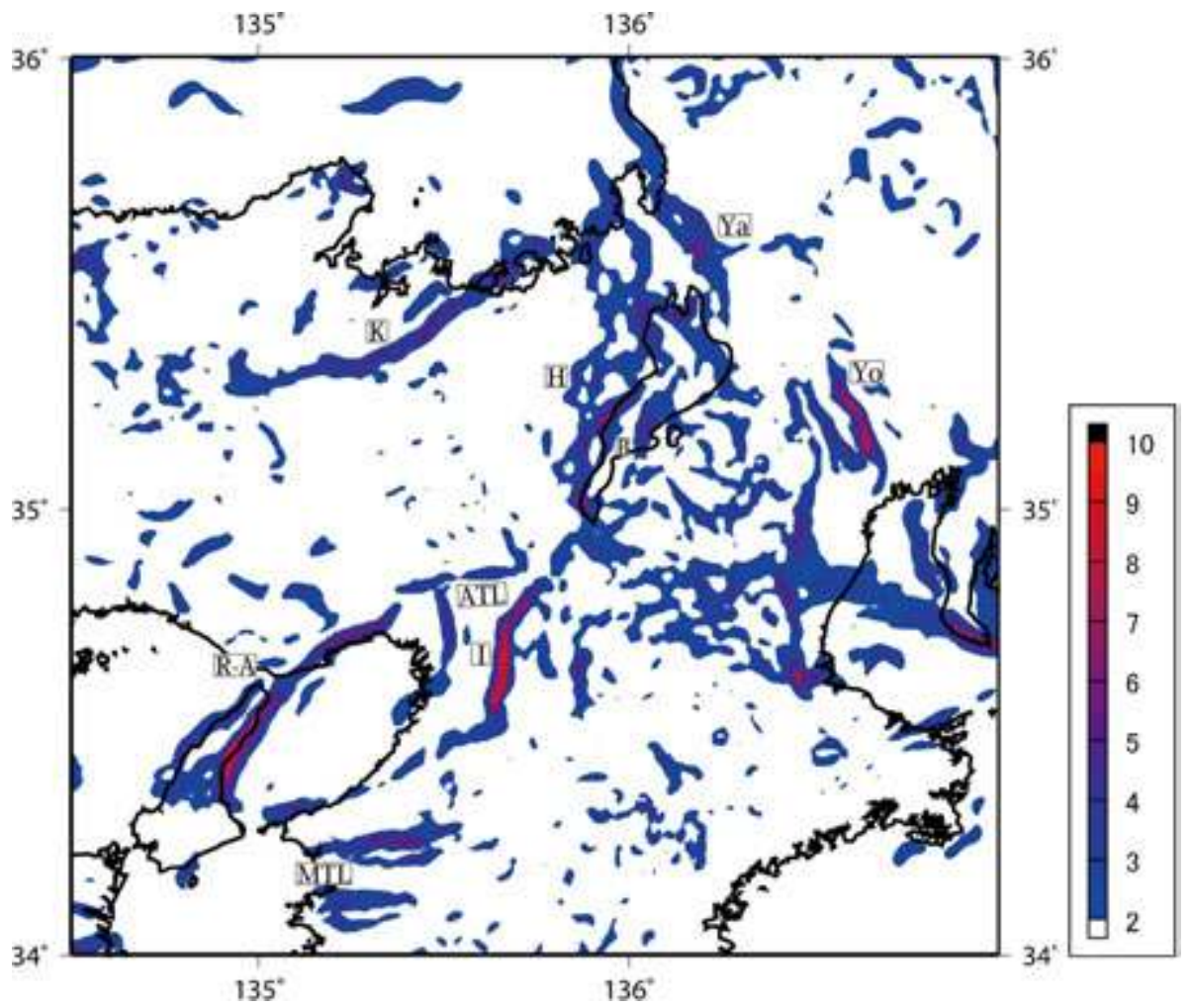

Figure 15. First order horizontal derivative of Bouguer gravity anomalies more than $2 \mathrm{mGal} / \mathrm{km}$. Contour intervals is 1 mGal/km. MTL: Median Tectonic Line, ATL: Arima Takatsuki Tectonic Line, R-A: Rokko-Awaji Fault zone, I: Ikoma Fault zone, K: Kambayashi Fault, H: Hanaore Fault, B: Biwako-seigan Fault zone, Ya: Yanagase Fault zone, Yo: Yoro Fault zone

\section{Summary}

The present Lake Biwa is a tectonic basin under the E-W compressional stress state. Distribution of active faults is characterized by the western boundary of the lake (Biwako-seigan Fault zone; Hira, Katata Faults with N-S direction) and the northeast region of Lake (Yanagase Fault etc). Activity of faults (mainly Biwako-seigan Fault zone) of more than $1 \mathrm{~m} / \mathrm{kyr}$ along the west side of Lake Biwa is important for the present lake basin formation.

Basement topography revealed by the seismic reflection survey shows alignment of the valley and range with a N-S direction. The " $\mathrm{A}$ " horizon (bottom of T bed since about $0.43 \mathrm{Ma}$ ) topography of the seismic reflection profile revealed its tilting topography from east to west. The sedimentary record from present Lake Biwa by deep drilling includes a shift of the lake depocenter from farther to the south to its current location. The sedimentary record shows 
constant sedimentation from at least 1.3 Ma. The sedimentation rate of the present Lake Biwa is about $0.57 \mathrm{~m} / \mathrm{kyr}$ as revealed by age depth curve of $1400-\mathrm{m}$ deep drilling core taken in 1982-1983. The subsidence rate is calculated as $0.74-\mathrm{m} / \mathrm{kyr}$ by data of the T bed (thickness 250 $\mathrm{m}$, duration $430 \mathrm{kyr}$, water depth $68 \mathrm{~m}$ ).

Paleogeographic evidence since Pliocene in central Kinki district including Paleo-Lake Biwa area shows the characteristics by which the history of this basin has been divided into two main stages; the Older and the Actual. Deposits of the Older Stage are distributed mainly southward of the present Lake Biwa. The sedimentary depocenter of the Older Stage was located south of the modern Lake Biwa. The depocenter evidently shifted northward to its present location creating the modern Lake Biwa Basin. Those changes and basin migration since the Pliocene are regarded as tectonic basin formation under the influence of superposed two tectonic stress states represented by upheaving of the southern area and tilting of eastern area. Tectonic stress change from a N-S compressional stress state to the E-W one was conspicuous.

Lake Biwa area (Ohmi Plain) is a large negative gravity anomaly area in the 'Kinki-Triangle' area with $-60 \mathrm{mGal}$ indicating the inhomogeneity of lower crust, or lower crust thickness or existence of very low density materials because of faulting. Distribution of high gradient anomalies around Lake Biwa is extremely complex. It is difficult to find a specific trend in the strike directions of the horizontal gradient of the gravity anomaly, perhaps because they reflect subsurface structures because of extreme crustal activities including faulting during the Quaternary.

\section{Acknowledgements}

We thank Dr. Daisuke Ishimura, Miss Yurie Yamamoto, Mr. Keitaro Yamada for help on preparing the figures.

\section{Author details}

Keiji Takemura ${ }^{1}$, Tsuyoshi Haraguchi ${ }^{2}$, Shigekazu Kusumoto ${ }^{3}$ and Yasuto Itoh ${ }^{4}$

1 Beppu Geothermal Research Laboratory, Institute for Geothermal Sciences, Graduate School of Science, Kyoto University, Noguchibaru, Beppu, Japan

2 Graduate School of Science, Osaka City University, Osaka, Japan

3 Graduate School of Science and Engineering for Research, University of Toyama, Toyama, Japan

4 Graduate School of Science, Osaka Prefecture University, Osaka, Japan 


\section{References}

[1] Nakata, T. and Imaizumi, T. eds. Digital Active Fault Map of Japan. University of Tokyo Press 2002, 2 DVD-ROM, 60p, 1 appended figure.

[2] Horie S., Mitamura, O., Kanari, S., Miyake, H., Yamamoto, A. and Fuji, N. Paleolimnological study on lacustrine sediments of Lake Biwa-ko. Contribution from the Geological Institute, Kanazawa University 1971; 18: 745-762.

[3] Horie S. Lake Biwa. Dr W Junk Publishers: 1984; 654pp.

[4] Takemura K., Iwabe, C., Hayashida, A., Danhara, T., Kitagawa, H., Hraguchi, T., Sato, T. and Ishikawa, N. Stratigraphy of marker tephras and sediments during past 50,000 years from multiple sites in Lake Biwa, Japan, The Quaternary Research Japan 2010; 49: 147-160 (in Japanese with English abstract)

[5] Takemura K. Tectonic and climatic record of the Lake Biwa, Japan, region provided by the sediments deposited since Pliocene times. Palaeogeography, Palaeoclimatology, Palaeoecology 1990; 78: 185-193.

[6] Horie S. Die Geschichte des Biwa-See in Japan: seine Entwicklung, dargestellt anhand eines $1400 \mathrm{~m}$ langen Tiefbohrkerns. Universitatsverlag Wagner: 1991; 349pp.

[7] Yoshikawa S and Inouchi Y. Tephrostratigraphy of the Takashima-oki boring core samples from Lake Biwa, central Japan. Chikyu Kagaku (Earth Science) 1991; 45: 81100 (in Japanese with English abstract)

[8] Takemura K., Hayashida, A., Okamura, M., Matsuoka, H., Ali, M., Kuniko, Y. and Tori, M. Stratigraphy of multiple piston-core sediments for the last 30,000 years from Lake Biwa, Japan. Journal of Paleolimnology 2000; 23(2): 185-199

[9] Takemura, K. and Yokoyama, T. Sedimentary facies of the 1,400 m drilling sample from Lake Biwa with reference to the discontinuity in the sedimentary sequence. IPPCCE NEWSLETTER 1989; 5: 36-48.

[10] Yokoyama, T. and Takemura, K. Geologic column obtained by the deep drilling from the bottom surface of Lake Biwa, Japan. IPPCCE Newsletter 1983; 3: 21-23.

[11] Meyers, P. A., Takemura, K. and Horie, S. Reinterpretation of Late Quaternary sediment chronology of Lake Biwa, Japan, from correlation with marine glacial-interglacial cycles, Quaternary Research 1993; 39: 154-162.

[12] Nakagawa, T., Gotanda, K., Haraguchi, T., Danhara, T., Yonenobu, H., Brauer, A., Yokoyama, Y., Tada, R., Takemura, K., Staff, R. A., Payne, R., Bronk Ramsey, C., Bryant, C., Brock, F., Schlolaut, G., Marshall, W., Tarasov, P., Lamb, H., Suigetsu 2006 Project Members SG06, a fully continuous and varved sediment core from Lake Suigetsu, Japan: stratigraphy and potential for improving the radiocarbon calibration 
model and understanding of late Quaternary climate changes. Quaternary Science Review 2012; 36: 164-176 doi:10.1016/j.quascirev.2010.12.013

[13] Danhara T., Yamashita, T., Iwano, H., Takemura, K. and Hayashida, A. Re-investigation of chronology for the $1400 \mathrm{~m}$ sediment core obtained from the Lake Biwa in 19821983. The Quaternary Research (Jpana) 2010; 49: 101-119 (in Japanese with English abstract)

[14] Machida H and Arai F. Atlas of Tephra in and around Japan. University of Tokyo Press; 2003, 336 pp (in Japanese)

[15] Sato, T., Danhara, T., Haraguchi, T., Hayashida, A. and Takemura, K. Sedimentation rate and relative lake-level change during last $300 \mathrm{ky}$ in Lake Biwa, Japan. Annual meeting of Japan Geoscience Union; 2009 (Makuhari, Chiba, Japan).

[16] Huzita, K. Ro1e of the Median Tectonic Line in the Quaternary tectonics of the Japanese Islands. Mem. Geol. Soc. Japan 1980; (18) 129-153.

[17] The Headquarters for Earthquake Promotion, Long term evaluation of Biwako-seigan Fault zone. 2009.

[18] Okada, A. and Togo, M. Active faults in Kinki. University of Tokyo Press; 2000: 395p.

[19] Horie, S. ed. Paleolimnology of Lake Biwa and the Japanese Pleistocene; 11, 99p, Institute of Paleolimnology and Paleoenvironment on Lake Biwa of Kyoto University; 1983.

[20] Komazawa, M. Gravity grid database of Japan. Gravity CD-ROM of Japan, ver. 2, Digital Geoscience Map P-2: Geological Survey of Japan; 2004.

[21] Huzita K. The Quaternary tectonic stress states of Southwest Japan. Journal of Geosciences, Osaka City University 1976; 20: 93-103.

[22] Nakagawa, K., Ryoki, K., Muto, N., Nishimura, S., and Ito, K., Gravity anomaly map and inferred basement structure in Osaka Plain, central Kinki, south-west Japan. Journal of Geosciences, Osaka City University 1991; 34: 103-117

[23] Inoue, N., N. Kitada, Y. Itoh, K. Takemura, and Nakagawa, K. Integrated study of high resolution geophysical and geological information of Osaka Bay, Southwest Japan. Journal of Asian Earth Sciences 2003; 22: 1-11.

[24] Nishida J, Katsura I, Nishimura S. Gravity survey around Lake Biwa, Southwest Japan. Journal of Physics of the Earth 1990; 38: 1-17.

[25] Ikebe, N. Cenozoic geohistory of Japan. Proc. $8^{\text {th }}$ Pacific Science Congress 1956; 2: 446-456.

[26] Yokoyama, T. Tephrochronology and paleogeography of the Plio-Pleistocene in the eastern Setouchi Geologic province, southwest Japan. Mem. Fac. Sci. Kyoto University, Geol. \& Mineral. 1969; 36: 19-85. 
[27] Yokoyama, T. Stratigraphy of the Quaternary System around Lake Biwa and geohistory of the ancient Lake Biwa. In: Lake Biwa. Horie, S. (ed.) The Hague, Dr. W. Junk; 1984: 43-128.

[28] Yokoyama, T., Makinouchi, T., Takemura, K., Hayashida, A., Sannomiya, T. and Yamamura, H. Stratigraphy of the Pliocene Iga-Aburahi Formation of the Kobiwako Group at the east of Iga-Ueno City, Mie Prefecture, Japan. Paleolimnology of Lake Biwa and the Japanese Pleistocene 1980; 8: 45-64.

[29] Yokoyama, T., Ishida, S., Danhara, T., Hayashida, S., Hayashi, T., Hayashida, A., Nakagawa, Y., Nakajima, T., Natsuhara, N., Nishida, J., Otofuji, Y., Sakamoto, M., Takemura, K., Tanaka, N., Torii, M., Yamada, K., Yoshikawa, S. and Horie, S. Lithofacies of the $1000 \mathrm{~m}$ core samples on the east coast of Lake Biwa, Japan. Paleolimnology of Lake Biwa and the Japanese Pleistocene 1976; 4: 52-66.

[30] Takemura, K., Nishimura, S., Danhara, T. and Yokoyama, T. Properties and fission track age of volcanic ashes in the $1000 \mathrm{~m}$ core sample of Lake Biwa with special reference to correlation by tephra among the $1000 \mathrm{~m}, 200 \mathrm{~m}$ boring core samples of Lake Biwa and the Kobiwako Group. Paleolimnology of Lake Biwa and the Japanese Pleistocene 1976; 4: 79-95.

[31] Takemura, K., Iida, Y. and Yokoyama, T. Mineral composition and origin of sand grains in the 1,000 $\mathrm{m}$ core sample and at the coast and rivers around Lake Biwa, Japan. Paleolimnology of Lake Biwa and the Japanese Pleistocene 1979; 7: 78-99.

[32] Takemura, K. The Plio-Pleistocene Tokai Group and the tectonic development around Ise Bay of central Japan since Pliocene. Memoirs of the Faculty of Science, Kyoto University, Series of Geology \& Mineralogy 1985; 51: 21-96.

[33] Kuwahara, T. The Noobi Plain and its fault block movements. Quaternary Research (Japan) 1968; 7: 235-247.

[34] Huzita, K. Tectonic development of southwest Japan in the Quaternary Period. Journal of Geosciences, Osaka City University 1969; 12: 53-70. 
